\title{
ANALISIS PEMASARAN CABAI MERAH (CAPSICUM ANNUM, L.) DI KECAMATAN BENDAHARA KABUPATEN ACEH TAMIANG
}

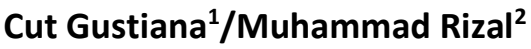 \\ ${ }^{1}$ Dosen Prodi Agribisnis Fakultas Pertanian \\ ${ }^{2}$ Alumni Prodi Agribisnis Fakultas Pertanian \\ UNIVERSITAS SAMUDRA
}

\section{RINGKASAN}

Analisis Pemasaran Cabai Merah (Capsicum annum, L.) Di Kecamatan Bendahara Kabupaten Aceh Tamiang. Tujuan Penelitian adalah untuk mengetahui efisiensi pemasaran cabai merah di kecamatan Bendahara Kabupaten Aceh Tamiang. Penelitian ini dilakukan dengan menggunakan metode survey. Lokasi penelitian di Kecamatan Bendahara Kabupaten Aceh Tamiang dengan pertimbangan bahwa kecamatan tersebut terdapat petani yang melakukan kegiatan usahatani cabai merah. Penentuan desa sampel dilakukan dengan menggunakan metode Simple Random Sampling, jumlah sampel diambil 30\% dari jumlah populasi yaitu sebanyak 32 orang.

Hasil penelitian: Karakteristik petani dan pedagang yaitu rata-rata umur petani cabai merah 39,90 tahun dengan pendidikan rata-rata 9,65 tahun berarti petani cabai merah di kecamatan Bendahara rata-rata Sekolah Lanjutan Tingkat Pertama (SLTP) dengan jumlah tanggungan keluarga sebanyak 4 orang dan pengalaman berusahatani selama 9,65 tahun. Rata-rata umur agen dan pedagang cabai merah yaitu berumur 40,33 tahun dengan pendidikan rata-rata 8,44 tahun berarti pedagang cabai merah di kecamatan Bendahara rata-rata Sekolah Lanjutan Tingkat Pertama (SLTP) dengan jumlah tanggungan keluarga sebanyak 3 orang dan pengalaman berusahatani selama 8,00 tahun.

Terdapat tiga saluran pemasaran cabai merah yang digunakan petani di Kecamatan Bendahara dalam menyampaikan hasil produksinya, yaitu : saluran pemasaran I, saluran pemasaran II dan saluran pemasaran III. Rata-rata saluran pemasaran yang paling banyak mengeluarkan biaya pemasaran adalah saluran pemasaran I yaitu sebesar Rp. 723, sedangkan yang paling sedikit mengeluarkan biaya pemasaran adalah saluran pemasaran III yaitu Rp. 186,-. Rata-rata margin pemasaran yang paling besar ialah pedagang pengecer pada saluran pemasaran III yaitu sebesar Rp. 5.367,-, sedangkan ratarata margin pemasaran yang paling sedikit didapat adalah oleh agen kecamatan pada saluran pemasaran I yaitu sebesar Rp. 2.250. Saluran pemasaran yang paling efisien yaitu terdapat pada saluran pemasaran II dengan rata-rata efisiensi pemasaran dari sisi share price adalah $80,68 \%$. Apabila dilihat dari sisi biaya pemasaran cabai merah di Kecamatan Bendahara efisien, hal ini karena nilai ( $\geq$ $50 \%)$.

Kata Kunci: Cabai Merah, Saluran, Margin, Biaya, Efisiensi Pemasaran

\section{PENDAHULUAN}

\section{Latar Belakang}

Pengembangan pertanian saat ini masih mempunyai peranan yang sangat strategis dalam pengembangan ekonomi, terutama konstribusinya terhadap ketahanan pangan, kesempatan kerja dan lapangan usaha. Keadaan geografis Negara Indonesia yang merupakan wilayah tropis, beriklim basah, serta berada di wilayah khatulistiwa sangat cocok dan mendukung untuk digunakan dalam budidaya tanaman, khususnya tanaman hortikultura.

Tanaman hortikultura merupakan salah satu tanaman yang menunjang pemenuhan gizi masyarakat sebagai sumber vitamin, mineral, protein, dan karbohidrat. Salah satunya adalah sayur-sayuran. Cabai merupakan produk hortikultura sayuran yang digolongkan ke dalam tiga kelompok yaitu cabai besar, cabai kecil dan cabai hias. Diantara ketiga jenis cabai tersebut, cabai besar merupakan jenis cabai yang paling banyak diperdagangkan dalam masyarakat.

Karena merupakan bahan pangan yang dikonsumsi setiap saat, maka cabai akan terus dibutuhkan dengan jumlah yang semakin meningkat seiring dengan pertumbuhan jumlah penduduk dan perekonomian nasional. Cabai selain berguna sebagai 
penyedap masakan, juga memiliki manfaat untuk kesehatan manusia antara lain sebagai penambah nafsu makan. Secara umum cabai memiliki banyak kandungan gizi dan vitamin diantaranya Kalori, Protein, Lemak, Karbohidrat, Kalsium, Vitamin A, B, dan Vitamin C. selain digunakan untuk keperluan rumah tangga, juga dapat digunakan untuk

\begin{tabular}{|c|c|c|c|c|}
\hline Tab & Desa & Luas (Ha) & Produksi (Ton) & Produktivitas (Ton/Ha) \\
\hline 1 & Alur Cantik & 1,50 & 8,61 & 5,74 \\
\hline 2 & Balai & 6,00 & 33,60 & 5,60 \\
\hline 3 & Bandar Baru & 5,00 & 36,00 & 7,20 \\
\hline 4 & Bandar Khalifah & 13,00 & 91,00 & 7,00 \\
\hline 5 & Cinta Raja & 20,00 & 140,00 & 7,00 \\
\hline 6 & Kuala Genting & 1,30 & 9,36 & 7,20 \\
\hline 7 & Kuala Peunaga & 15,00 & - & - \\
\hline 8 & Lambung Blang & 1,00 & 7,00 & 7,00 \\
\hline 9 & Lubuk Batil & 2,50 & 14,00 & 5,60 \\
\hline 10 & Marlempang & 4,00 & 30,00 & 7,50 \\
\hline 11 & Matang Teupah & - & & \\
\hline 12 & Mesjid BDH & 1,00 & 7,30 & 7,30 \\
\hline 13 & Mesjid & 6,00 & 44,40 & 7,40 \\
\hline 14 & S.lyu Raja & - & - & - \\
\hline 15 & Rantau Pakam & 6,00 & 35,00 & 5,83 \\
\hline 16 & Seunebok Aceh & 3,00 & 22,20 & 7,40 \\
\hline 17 & Seunebok Dalam.M & 3,00 & 21,90 & 7,30 \\
\hline 18 & Seunebok Dalam.U & 3,00 & 22,50 & 7,50 \\
\hline 19 & Suka Mulia & 5,00 & 35,00 & 7,00 \\
\hline 20 & BDH Tanjung & - & - & - \\
\hline 21 & Tanjung Binjai & 3,00 & 22,50 & 7,50 \\
\hline 22 & Tanjung Lipat I & 6,50 & 37,50 & 5,77 \\
\hline 23 & Tanjung Lipat II & 1,50 & 11,25 & 7,50 \\
\hline 24 & Tanjung Mulia & - & - & - \\
\hline 25 & Tanjung Parit & - & - & - \\
\hline 26 & Teluk Halban & - & - & - \\
\hline 27 & Teluk Kemiri & 1,50 & 10,80 & 7,20 \\
\hline 28 & Teluk Kepayang & 4,00 & 28,80 & 7,20 \\
\hline 29 & Teungku Tinggi & - & - & - \\
\hline 30 & Tumpuk Tengah & - & - & - \\
\hline 31 & Upah & - & - & - \\
\hline 32 & Kebun S. Iyu & - & - & - \\
\hline \multirow[t]{3}{*}{33} & Pondok & - & - & - \\
\hline & Jumlah & 112,80 & 668,72 & 144,74 \\
\hline & Rata-rata & 5,37 & 31,84 & 6,89 \\
\hline
\end{tabular}

Sumber: Data Sekunder keperluan industri diantaranya, Industri bumbu masakan, Industri makanan, Industri obat-obatan atau jamu (Setiadi, 2008: 10). Adapun luas tanam, produksi dan produktivitas cabai merah Kecamatan Bendahara sebagai berikut: 
Berdasarkan Tabel tersebut, dapat kita lihat bahwa di Kecamatan Bendahara terdapat 33 desa. Adapun rata-rata luas tanam, produksi dan produktivitas cabai merah di Kecamatan Bendahara yaitu: luas tanam 5,37 $\mathrm{Ha}$, produksi 31,84 Ton dan produktivitas adalah 6,89 Ton / Ha.

Secara umum cabai memang bisa ditanam di sembarangan tempat, sembarangan daerah dan sembarangan waktu. Cabai bisa ditanam pada saat musim kemarau maupun musim hujan. Bertanam cabai merah dapat memberikan nilai ekonomi yang cukup tinggi karena tanaman cabai merah dapat diusahakan selama dua setengah tahun selama musim tanam. Walaupun demikian pada saat tertentu harga cabai dapat melonjak naik sehingga memberikan nilai tambah bagi petani.

Menurut pendapat Setiadi (2006: 13) saat ini cabai menjadi salah satu komoditas sayuran yang banyak dibutuhkan masyarakat, baik masyarakat lokal maupun internasional. Setiap harinya permintaan cabai semakin bertambah seiring dengan meningkatnya jumlah penduduk diberbagai Negara. Sehingga budidaya cabai ini menjadi peluang usaha yang sangat menjanjikan untuk pasar lokal bahkan pasar ekspor.

Berdasarkan data Badan Pusat Statistik Tahun 2014, produksi cabai merah di Aceh mencapai 945,90 kwintal, ini menunjukkan produktivitas cabai masih rendah karena tidak mencukupi banyaknya permintaan. Banyaknya produksi cabai bergantung pada permintaan, penawaran dan harga barang lain seperti cabai rawit.

Harga cabai merah di Kabupaten Aceh Tamiang mengalami fluktuasi. Harga cabai mengalami kenaikan pada saat dimana permintaan cukup banyak sedangkan ketersediaan cabai sedikit. Harga cabai mengalami penurunan ketika penawaran banyak sedangkan permintaan tetap, dimana terjadi panen raya.

Analisis pemasaran merupakan suatu analisis yang dilakukan untuk mengetahui tingkat keuntungan yang diperoleh petani dalam hal pemasaran cabai merah. Salah satu peran penting dari pemasaran cabai merah adalah terbentuknya saluran pemasaran yang sistematis, terutama terlibatnya lembaga perantara sepe rti pedagang pengecer. Pemasaran cabai merah di Kecamatan Bendahara sebagian besar petani jual langsung kepada pengecer di pasar.

\section{Identifikasi Masalah}

Apakah pemasaran cabai merah di Kecamatan Bendahara Kabupaten Aceh Tamiang sudah efisien?"

\section{Tujuan Penelitian}

Untuk mengetahui efisiensi pemasaran cabai merah di kecamatan Bendahara Kabupaten Aceh Tamiang.

\section{Hipotesis}

Pemasaran cabai merah di Kecamatan Bendahara Kabupaten Aceh Tamiang sudah efisien.

\section{METODOLOGI PENELITIAN}

\section{Lokasi, Objek, Ruang Lingkup dan Waktu penelitian}

Metode penelitian yang digunakan dalam penelitian ini adalah metode survey. Menurut Nazir (2009: 550), "Metode survey adalah penyelidikan untuk memperoleh fakta dari gejala-gejala dan mencari keteranganketerangan secara faktual, baik tentang institusi sosial, ekonomi ataupun politik dari suatu kelompok atau suatu daerah". Lokasi penelitian yaitu Kecamatan Bendahara Kabupaten Aceh Tamiang, Objek dalam penelitian ini hanya dibatasi pada petani, pedagang, agen, pengecer yang melakukan penjualan cabai merah yang ada di Kecamatan Bendahara Kabupaten Aceh Tamiang. Ruang lingkup penelitian ini meliputi pemasaran cabai merah di kecamatan Bendahara Kabupaten Aceh Tamiang. Waktu penelitian dilaksanakan pada bulan Maret 2016 di Kecamatan Bendahara Kabupaten Aceh Tamiang.

Teknik Penentuan

Sampel dan

Pengumpulan Data 
Kecamatan Bendahara Kabupaten Aceh Tamiang terdiri dari 33 desa. Dari 33 desa diambil 4 desa secara Purposive Sampling. Sugiyono (2008: 11) mengemukakan Purposive Sampling adalah sampling yang dilakukan dengan pertimbangan tertentu. Desa- desa yang dipilih dalam penelitian ini dengan pertimbangan bahwa desa-desa tersebut merupakan daerah yang memiliki usahatani cabai merah.

Pengambilan sampel dilakukan dengan menggunakan metode Simple Random Sampling (Sampel Acak sederhana). Nazir, M (2009: 23) menyatakan bahwa Simple Random Sampling adalah pengambilan sampel dari populasi dimana tiap unit populasi mempunyai peluang yang sama untuk dipilih. Sedangkan Sudjana (2005: 13)

Tabel III-1 Jumlah Populasi dan Petani Sampel Cabai Merah di Kecamatan Bendahara Kabupaten Aceh Tamiang

\begin{tabular}{|c|l|c|c|}
\hline No. & \multicolumn{1}{|c|}{ Desa Sampel } & $\begin{array}{c}\text { Jumlah Populasi } \\
\text { (Orang) }\end{array}$ & $\begin{array}{c}\text { Jumlah Sampel } \\
\text { (Orang) }\end{array}$ \\
\hline 1 & Alur Cantik & 22 & 7 \\
2 & Kuala Geunting & 18 & 6 \\
3 & Matang Teupah & 35 & 11 \\
4 & Rantau Pakam & 25 & 8 \\
\hline Jumlah & & 100 & 32 \\
\hline
\end{tabular}

Sumber: Data primer (diolah)

Dari Tabel III-1 dapat dilihat bahwa jumlah sampel seluruhnya yaitu sebanyak 30 orang yang terdiri dari Desa Alur Cantik dengan jumlah sampel 7 orang, Desa Kuala Geunting 5 orang, Desa Matang Teupah 10 Orang dan Desa Rantau Pakam 8 Orang.

Lembaga pemasaran dalam penelitian ini terdiri dari 3 lembaga pemasaran yaitu: Tabel III-2 Jumlah Populasi dan Sampel Lembaga Pemasaran Pada Usahatani Cabe Merah diKecamatan Bendahara Kabupaten Aceh Tamiang

\begin{tabular}{|c|c|c|c|}
\hline No. & Lembaga Pemasaran & $\begin{array}{c}\text { Jumlah Populasi } \\
\text { (Orang) }\end{array}$ & $\begin{array}{c}\text { Jumlah Sampel } \\
\text { (Orang) }\end{array}$ \\
\hline 1 & Pedagang Pengumpul Desa & 4 & 4 \\
\hline 2 & Pedagang Kecamatan & 3 & 3 \\
\hline 3 & Pedagang Pengecer & 2 & 2 \\
\hline \multicolumn{2}{|c|}{ Jumlah } & 9 & 9 \\
\hline
\end{tabular}

Sumber: Data primer (diolah)

Berdasarkan tabel III-2 dapat dilihat bahwa lembaga pemasaran untuk pedagang pengumpul desa sebanyak 4 orang, pedagang kecamatan 3 orang dan pedagang pengecer 2 orang sehingga menyatakan: "bila populasi kecil, sampel dirumuskan mendekati jumlah populasi, misalnya bila populasi 1000 kasus menarik sampel $10-20 \%$ telah cukup memadai, namun bila populasi 50 kasus sampel tidak kurang dari 20\%". Besarnya sampel yang diambil adalah $30 \%$ dari jumlah petani di daerah penelitian.

Wirartha (2006: 238) mengemukakan dalam sampel random sederhana, anggota populasi tidak dipilah-pilah atau distrata terlebih dahulu. Semua anggota populasi langsung dipilih secara random (acak). Penelitian langsung merandom atau mengacak untuk mendapatkan ukuran sampel yang diinginkan. Adapun jumlah sampel dapat dilihat pada Tabel III-1 sebagai berikut:

pedagang desa, pedagang kecamatan dan pedagang pengecer. Pengambilan sampel untuk lembaga pemasaran dilakukan dengan metode pengambilan sampel secara sensus, hal ini dikarenakan jumlah populasi lembaga pemasaran di daerah penelitian relatif kecil. Adapun jumlah lembaga pemasaran di daerah penelitian adalah sebagai berikut: jumlah seluruh lembaga pemasaran dalam hal ini agen dan pedagang berjumlah seluruhnya 9 orang. Data yang dikumpulkan dalam penelitian ini meliputi data primer dan data sekunder. 
Metode Analisis dan Pengujian Hipotesis

Data yang diperoleh dari lapangan

terlebih dahulu ditabulasi secara sederhana dan selanjutnya dianalisis sesuai dengan metode yang sesuai.

a. Margin Pemasaran

$\mathrm{Mji}=$ Pri-Pfi atau $\mathrm{Mji}=\mathrm{bi}+\mathrm{Ki}$

(Soekartawi, 2002: 54)

Dimana:

Mji = Margin penyaluran cabai Pri = harga di tingkat distributor $\mathrm{Pfi}=$ Harga di tingkat pengecer

$\mathrm{Bi}=$ Biaya penyaluran

$\mathrm{Ki}=$ Keuntungan

b. Share Price

$\mathrm{SP}=\mathrm{Pp} / \mathrm{Pk}$

$\mathrm{SP}=$ Persentase biaya

$\mathrm{Pp}=$ Harga yang diterima produsen dan pedagang

$\mathrm{Pk}=$ harga yang dibayar konsumen akhir

c. Efisiensi Pemasaran

$E P=T B / T N P \times 100 \%$

$\mathrm{EP} \quad=$ Efisiensi Pemasaran

TB = Total Biaya Pemasaran

TNP $=$ Total Nilai Produk

Dengan kaidah keputusan :

$\mathrm{SP}>50 \%$ (Efisien)

$\mathrm{SP}<50 \%$ (Tidak Efisien)

\section{HASIL PENELITIAN DAN \\ PEMBAHASAN}

\section{Karakteristik Petani dan Pedagang}

Rata-rata umur petani cabai merah yaitu berumur 39,90 tahun dengan pendidikan rata-rata 9,65 tahun berarti petani cabai merah di kecamatan Bendahara rata-rata Sekolah Lanjutan Tingkat Pertama (SLTP) dengan jumlah tanggungan keluarga sebanyak 4 orang dan pengalaman berusahatani selama 9,65 tahun. Rata-rata umur agen dan pedagang cabai merah yaitu berumur 40,33 tahun dengan pendidikan rata-rata 8,44 tahun berarti pedagang cabai merah di kecamatan Bendahara rata-rata Sekolah Lanjutan Tingkat Pertama (SLTP) dengan jumlah tanggungan keluarga sebanyak 3 orang dan pengalaman berusahatani selama 8,00 tahun.

Berdasarkan hal tersebut dapat diketahui bahwa umur responden yang terlibat dalam lembaga pemasaran di kecamatan Bendahara masih digolongkan umur produktif untuk bekerja. Penduduk

usia produktif yaitu penduduk umur 15 64 tahun (Mubyarto, 2008: 56). Umur produktif adalah umur dimana seseorang memiliki kemampaun untuk menghasilkan produk maupun jasa, dengan umur responden yang terlibat dalam lembaga pemasaran di kecamatan Bendahara maka dapat dikatakan masih memiliki semangat yang tinggi dan mudah mengadopsi hal- hal baru, sangat menunjang aktivitas lembaga pemasaran cabai merah karena sebagian besar lembaga pemasaran terlibat secara langsung dalam proses jual beli cabai merah mulai dari petani hingga memasarkannya, sehingga memiliki kesempatan yang besar untuk memperluas segmen pasarnya dikarenakan selama berlangsungnya proses jual beli petani dan pedagang dapat memperoleh informasi- informasi.

\section{Saluran Pemasaran}

Saluran pemasaran dalam penelitian ini adalah jalur dari lembaga-lembaga pemasaran yang mempunyai kegiatan 
menyalurkan barang dari produsen dan konsumen. Pemasaran cabai merah di daerah penelitian umumnya melalui saluran pemasaran yang cukup panjang. Untuk sampai ke konsumen, harus melalui beberapa tahap yaitu dari petani, agen desa, agen kecamatan dan pedagang pengecer. Hal tersebut menyebabkan kesenjangan harga jual petani dan pedagang enceran yang cukup tinggi karena biaya tataniaga yang cukup besar dan kehilangan hasil selama proses pemasaran. Saluran pemasaran cabai merah dapat diketahui dengan cara mengikuti arus pemasaran cabai merah mulai dari petani sampai kepada konsumen. Saluran pemasaran cabai merah di daerah penelitian terdiri dari 3 saluran.

Berdasarkan penelitian yang telah di laksanakan, dapat diketahui saluran pemasaran cabai merah di daerah penelitian adalah sebagai berikut:

1. Saluran I : Petani---Agen Desa---Agen Kecamatan----Pedagang Pengecer----Konsumen

2. Saluran I : Petani---Agen Desa---Pedagang Pengecer----Konsumen

3. Saluran I : Petani---Agen Desa---Konsumen

Tabel V-3. Saluran Pemasaran dan Jumlah petani Responden di Kecamatan Bendahara

\begin{tabular}{|l|l|l|l|}
\hline No & Saluran Pemasaran & Jumlah Petani & Persentase\% \\
\hline 1 & Saluran I & 8 & 26,66 \\
2 & Saluran II & 7 & 23,34 \\
3 & Saluran III & 15 & 50,00 \\
\hline
\end{tabular}

Sumber : Data primer diolah

Berdasarkan tabel V- 3 diatas dapat dilihat bahwa saluran pemasaran yang paling banyak digunakan petani adalah saluran pemasaran III yaitu sebanyak 15 orang (50,00\%) dimana petani langsung menjual cabai merah kepada pedagang pengecer, ini menunjukkan hanya melibatkan dua lembaga pemasaran dan biaya yang dikeluarkan lebih kecil. Selanjutnya saluran I sebanyak 8 orang $(26,66 \%)$ dan saluran II sebanyak 7 orang (23,33\%). Saluran pemasaran III paling banyak di bandingkan saluran I dan II sehingga keuntungan yang diperoleh petani lebih banyak di bandingkan dengan menggunakan saluran I dan II.

\section{Biaya Pemasaran Cabai merah}

Biaya pemasaran adalah biaya yang dikeluarkan untuk menjual hasil produksi ke pasar. Menurut Mulyadi (2002: 529) biaya pemasaran adalah semua biaya yang sejak saat produk selesai diproduksi dan disimpan dalam gudang sampai dengan produk tersebut berubah kembali dalam bentuk uang tunai. Proses mengalirnya barang dari produsen ke konsumen memerlukan biaya, dengan adanya biaya pemasaran maka suatu produk akan meningkat harganya. Semakin panjang rantai pemasaran maka biaya yang dikeluarkan dalam pemasaran akan semakin meningkat. Selain itu, besarnya biaya pemasaran suatu produk tergantung pada jenis perlakuan terhadap produk itu sendiri. Untuk lebih jelasnya rata-rata pengunaan biaya pemasaran cabai merah di Kecamatan Bendahara dapat dilihat pada tabel V-5 berikut:

Tabel V-5. Rata-rata Biaya Pemasaran cabai merah di Kecamatan Bendahara,

\begin{tabular}{|l|c|c|c|c|c|c|}
\hline No & \multirow{3}{*}{$\begin{array}{c}\text { Saluran } \\
\text { Pemasaran }\end{array}$} & Petani & $\begin{array}{c}\text { Pedagang } \\
\text { Desa }\end{array}$ & $\begin{array}{c}\text { Pedagang } \\
\text { Kecamatan }\end{array}$ & $\begin{array}{c}\text { Pedagang } \\
\text { Pengencer }\end{array}$ & $\begin{array}{c}\text { Jotal } \\
\text { (Rp/Kg) }\end{array}$ \\
\cline { 3 - 6 } & I & 195 & 350 & 213 & 160 & 723 \\
2 & II & 195 & 0 & 324 & 259 & 583 \\
3 & III & 195 & 0 & 0 & 186 & 186 \\
\hline
\end{tabular}

Sumber : Data primer diolah 
Berdasarkan tabel V-5 di atas dapat dilihat bahwa rata-rata saluran pemasaran yang paling banyak mengeluarkan biaya pemasaran adalah saluran pemasaran I yaitu sebesar Rp. 723, hal ini terjadi karena pada saluran pemasaran I petani banyak melibatkan lembaga pemasaran yaitu dari agen desa ke agen kecamatan baru ke pedagang pengecer.

Sedangkan saluran pemasaran yang paling sedikit mengeluarkan biaya pemasaran adalah saluran pemasaran III yaitu Rp. 186,hal ini disebabkan karena pada saluran pemasaran III petani hanya melibatkan satu lembaga pemasaran yaitu langsung menjual kepada pedagang pengecer sehingga biaya yang dikeluarkan lebih sedikit.

\section{Margin Pemasaran Cabai Merah}

Margin Pemasaran adalah selisih harga yang dibayar konsumen akhir dan harga yang diterima oleh petani produsen. Margin pemasaran sering digunakan sebagai indikator efisiensi pemasaran. Besarnya margin pemasaran pada berbagai saluran pemasaran dapat berbeda, karena tergantung pada panjang pendeknya saluran pemasaran dan aktivitas-aktivitas yang telah dilaksanakan serta keuntungan yang diharapkan oleh lembaga pemasaran yang terlibat dalam pemasaran. Untuk lebih jelasnya mengenai rata-rata margin dan keuntungan pemasaran cabai merah didaerah penelitian dapat dilihat pada tabel V-6 berikut:

Tabel V-6. Rata-rata Margin Pemasaran di Kecamatan Bendahara, 2015

\begin{tabular}{|c|c|c|c|c|c|}
\hline \multirow{2}{*}{ No } & \multirow[b]{2}{*}{$\begin{array}{c}\text { Saluran } \\
\text { Pemasaran }\end{array}$} & \multicolumn{3}{|c|}{ Margin Pemasaran ( $\mathrm{Rp} / \mathrm{Kg})$} & \multirow[b]{2}{*}{$\begin{array}{r}\text { Jumlah } \\
\text { (Rp/Kg) }\end{array}$} \\
\hline & & $\begin{array}{c}\text { Pedagang } \\
\text { Desa }\end{array}$ & $\begin{array}{l}\text { Pedagang } \\
\text { Kecamatan }\end{array}$ & $\begin{array}{l}\text { Pedagang } \\
\text { Pengencer }\end{array}$ & \\
\hline 1 & 1 & 2.750 & 2.250 & 3.250 & 8.250 \\
\hline 2 & II & 0 & 4.000 & 3.429 & 7.429 \\
\hline 3 & III & 0 & 0 & 5.367 & 5.367 \\
\hline
\end{tabular}

Sumber : Data primer diolah

Berdasarkan tabel V-6 di atas dapat dilihat bahwa rata-rata margin pemasaran yang paling besar ialah pedagang pengecer pada saluran pemasaran III yaitu sebesar Rp. 5.367,-, hal ini disebabkan pedagang pengecer langsung membeli cabaimerah dari petani dengan jarak tempuh yang jauh untuk meminimalisasi biaya pemasaran. Sedangkan rata-rata margin pemasaran yang paling sedikit di dapat adalah oleh agen kecamatan pada saluran pemasaran I yaitu sebesar Rp. 2.250,-. Sedangkan jumlah margin pemasaran terkecil terdapat pada pedagang kecamatan saluran pemasaran I yaitu Rp. 2.250, hal ini terjadi karena pada saluran pemasaran I melibatkan saluran pemasaran yang panjang sehingga biaya yang dikeluarkan lebih besar.

\section{Share Margin Pemasaran}

Share margin adalah salah satu cara untuk mengetahui tingkat efisiensi suatu pemasaran. Share Margin yang dimaksud dalam penelitian ini adalah bagian yang diterima oleh masing-masing lembaga pemasaran. Dari hasil perhitungan Share Margin dapat diketahui besar margin keuntungan yan diterima oleh masingmasaing lembaga pemasaran. Untuk jelasnya tentang rata-rata Share Margin yang diterima oleh tiap-tiap lembaga pemasaran didaerah penelitian dapat dilihat pada tabel V-7 berikut ini. 
Tabel V-7. Rata-rata Share Margin yang diterima oleh tiap-tiap lembaga Pemasaran di Kecamatan Bendahara

\begin{tabular}{|c|c|c|c|c|}
\hline \multirow{2}{*}{ No } & \multirow{3}{*}{$\begin{array}{c}\text { Saluran } \\
\text { Pemasaran }\end{array}$} & $\begin{array}{c}\text { Agen } \\
\text { Desa }\end{array}$ & $\begin{array}{c}\text { Agen } \\
\text { Kecamatan }\end{array}$ & $\begin{array}{c}\text { Pedagang } \\
\text { Pengecer }\end{array}$ \\
\hline 1 & I & 70,54 & 80,36 & 88,39 \\
2 & II & 0,00 & 73,51 & 87,85 \\
3 & III & 0,00 & 0,00 & 79,72 \\
\hline
\end{tabular}

Sumber Data primer diolah

Berdasarkan tabel V-7 di atas dapat terlihat jumlah Share margin yang diterima oleh masing-masing lembaga pemasaran di daerah penelitian dalam pemasaran cabai merah. Dengan rata-rata share margin terbesar didapatkan oleh pedagang pengencer pada saluran I yaitu sebesar $88,39 \%$, sedangkan share margin terkecil didapatkan oleh agen desa pada saluran I yaitu sebesar $70,54 \%$, jumlah total share margin yang paling kecil dari ketiga saluran tersebut terdapat pada saluran III yaitu $79,72 \%$, hal tersebut dikarenakan lembaga pemasaran yang terlibat dalam saluran pemasaran tersebut hanya satu lembaga pemasaran yaitu pedagang pengencer.

\section{Efisiensi Pemasaran}

Efisiensi merupakan suatu ukuran keberhasilan yang dinilai dari segi besarnya sumber/ biaya untuk mencapai hasil dari kegiatan yang dijalakan. Ada 2 faktor yang sangat menentukan efisien tidaknya sebuah saluran pemasaran yakni keuntungan pemasaran dan harga jual/eceran. Hal ini sesuai dengan pendapat Sudiono (2004: 13) yang menyatakan bahwa: "efisiensi pemasaran terjadi bila biaya pemasaran dapat ditekan sehingga keuntungan pemasaran yang lebih tinggi". Makin kecil efisiensi pemasaran maka akan semakin efisien pemasaran itu.Untuk lebih jelasnya mengenai efisiensi pemasaran cabai merah, dapat dilihat pada tabel berikut:

Tabel V-8: Efisiensi Pemasaran Cabai Merah Dari Sisi Share Price di Kecamatan Bendahara

\begin{tabular}{|c|c|c|c|c|c|}
\hline \multirow{2}{*}{ No } & \multirow{2}{*}{$\begin{array}{c}\text { Saluran } \\
\text { Pemasaran }\end{array}$} & $\begin{array}{c}|c| \\
\text { Eedagang } \\
\text { Desa }\end{array}$ & $\begin{array}{c}\text { Pedagang } \\
\text { Kecamatan }\end{array}$ & $\begin{array}{c}\text { Pedagang } \\
\text { Pengecer }\end{array}$ & (\%) \\
\hline 1. & I & 70,54 & 80,36 & 88,39 & 79,76 \\
2. & II & 0,00 & 73,51 & 87,85 & 80,68 \\
3. & III & 0,00 & 0,00 & 79,72 & 79,72 \\
\hline
\end{tabular}

Sumber: Data primer diolah

Berdasarkan Tabel V-8 dapat

diketahui bahwa saluran pemasaran yang paling efisien yaitu terdapat pada saluran pemasaran II dengan rata-rata efisiensi pemasaran dari sisi share price adalah $80,68 \%$. Petani cabai merah di Kecamatan Bendahara tidak semua memilih saluran pemasaran yang paling efisien yaitu hanya 7 orang petani yang memilih saluran II. Hal ini disebabkan biaya yag dikeluarkan petani dalam memasarkan cabai merah lebih besar karena petani harus mengantar sendiri ke pedagang kecamatan.

Untuk melihat efisiensi pemasaran cabai merah dari sisi biaya pemasaran di Kecamatan Bendahara sebagaimana pada Tabel V-9 berikut: 
Tabel V-9 : Efisiensi Pemasaran Cabai Merah Dari Sisi Biaya Pemasaran di Kecamatan Bendahara

\begin{tabular}{|c|c|c|c|c|c|}
\hline \multirow[b]{2}{*}{ No } & \multirow[b]{2}{*}{$\begin{array}{c}\text { Saluran } \\
\text { Pemasaran }\end{array}$} & \multicolumn{3}{|c|}{ Efisiensi Dari Sisi Biaya Pemasaran (\%) } & \multirow[t]{2}{*}{ Total (\%) } \\
\hline & & $\begin{array}{c}\text { Pedagang } \\
\text { Desa }\end{array}$ & $\begin{array}{l}\text { Pedagang } \\
\text { Kecamatan }\end{array}$ & $\begin{array}{l}\text { Pedagang } \\
\text { Pengecer }\end{array}$ & \\
\hline 1. & I & 10,00 & 6,08 & 4,58 & 20,66 \\
\hline 2. & II & 0,00 & 8,11 & 6,47 & 14,58 \\
\hline 3. & III & 0,00 & 0,00 & 11,01 & 11,01 \\
\hline
\end{tabular}

Sumber: Data primer diolah

Berdasarkan tabel di atas dapat

dilihat bahwa ketiga saluran pemasaran cabai merah dari sisi biaya pemasaran di Kecamatan Bendahara efisien, hal ini karena nilai ( $\geq 50 \%)$.

\section{KESIMPULAN DAN SARAN}

\section{Kesimpulan}

Dari hasil penelitian dan pembahasan yang diperoleh dapat diambil sebuah kesimpulan yaitu:

1. Terdapat tiga saluran pemasaran cabai merah yang digunakan petani di Kecamatan Bendahara dalam menyampaikan hasil produksinya, yaitu : saluran pemasaran I, saluran pemasaran II dan saluran pemasaran III.

2. Rata-rata saluran pemasaran yang paling banyak mengeluarkan biaya pemasaran adalah saluran pemasaran I yaitu sebesar Rp. 723, sedangkan yang paling sedikit mengeluarkan biaya pemasaran adalah saluran pemasaran III yaitu Rp. 186,-.

3. Rata-rata margin pemasaran yang paling besar ialah pedagang pengecer pada saluran pemasaran III yaitu sebesar Rp. 5.367,-, sedangkan ratarata margin pemasaran yang paling sedikit didapat adalah oleh agen kecamatan pada saluran pemasaran I yaitu sebesar Rp. 2.250 .

4. Saluran pemasaran yang paling efisien yaitu terdapat pada saluran pemasaran II dengan rata-rata efisiensi pemasaran dari sisi share price adalah $80,68 \%$. Apabila dilihat dari sisi biaya pemasaran cabai merah di Kecamatan Bendahara efisien, hal ini karena nilai ( $\geq 50 \%$ ).
Saran

1. Perlu adanya upaya perbaikan kualitas cabai merah agar yang dihasilkan dapat diserap oleh pasar modern. Sehingga petani dapat memiliki alternatif lain kepada siapa cabai yang dihasilkannya akan dijual.

2. Untuk meningkatkan pendapatan, diharapkan petani melakukan penjualan produksinya dalam bentuk grading sehingga penerimaan ditingkat petani lebih tinggi.

\section{DAFTAR PUSTAKA}

Anindita. 2004. Pemasaran Hasil Pertanian. Papyrus, Surabaya. Kotler, Phillip. 2005. Dasar-dasar pemasaran. Erlangga, Jakarta

Massofa. 2008. Pengertian dan Faktorfaktor yang Mempengaruhi Produktivitas

Kerja, (On Line), http://massofa.wordpress.com, 15 Juli - 2015. Mubyarto, 2008. Pengantar Ekonomi Pertanian. Pustaka LP3ES, Jakarta. Nazir, M. 2009. Metode Penelitian. PT. Ghalia Indonesia, Jakarta

Prajnanta. 2004. Agribisnis Cabai Hibrida. Penebar Swadaya, Jakarta

Setiadi. 2006. Cabai Rawit Jenis dan Budaya. Penebar Swadaya, Jakarta

Sudiyono. 2002. Pemasaran Pertanian. Universitas Muhamadiyah Malang, Malang

Soekartawi. 2001. Analisis Usahatani. UIPress, Jakarta

Swastha, 2000, Pengantar Bisnis Modern, Pengantar Ekonomi Perusahaan Modern, Liberty, Jakarta.

Sudjana. 2005. Teknik Analisa Regresi dan Korelasi. Tarsito. Bandung 
Sugiyono, 2008. Metode Penelitian Kunatitatif Kualitatif dan R\&D. Alfabeta, Bandung

Wirartha. 2006. Metodologi Penelitian Sosial
Ekonomi. Andi, Yogyakarta Wiryanta. 2006. Bertanam Cabai pada Musim Hujan. Agromedia, Tangerang 